in the material to be used for the preparation of the " cancer extract." Thus most of the material available had to be rejected. After some time, however, an opportunity presented itself. A patient who had undergone Kraske's operation for an adeno-carcinoma of the rectum several years ago, died from recurrence. At the necropsy metastases were found in the peritonenm, liver, lungs, \&c. One of the masses in the liver was of exceptional size, somewhat larger than the egg of a goose. It was excised, care being taken to cut everywhere through macroscopically cancerous tissue. Microscopical examination of a piece of the tissue thus excised, for which I am indebted to Dr. K. H. Kettle, pathologist to the Cancer Hospital, showed only metastatic growth ; no liver tissue could be found. The cancerous material was now cat up, and was used for the preparation of extracts. An aqueous extract was made in the same way as the aqueous antigen extract of Wassermann is prepared. Another extract was made with 95 per cent. alcohol and was incubated at $60^{\circ} \mathrm{C}$. for several hours. These extracts were then tested, as is the custom in Wassermann's laboratories, and their dosage was determined. The results with the alcoholic extract were so unsatisfactory that it was cast away.

The further experiments were made with the aqueous extract only, 0.2 c.c. and 0.25 c.c. being used for the experiments recorded in the table. It was tested with syphilitic, cancerous, and normal sera, only inactivated sera being used. Purposely, some old sera were also tried. Repeated tests were made with several sera on different days and under slightly modified conditions. Most of the results are shown below :-

TABLE V.-Tests with Canoer Extract.

\begin{tabular}{|c|c|c|c|c|}
\hline Serum. & $\begin{array}{l}\text { Syphilitic } \\
\text { extract. }\end{array}$ & $\begin{array}{l}\text { Cancer } \\
\text { extract. }\end{array}$ & Control. & Notes. \\
\hline Case 1 & $t+t$ & ++- & $-\cdots-$ & Case 2, Table III. \\
\hline " " & $+t+$ & ++- & $--\cdots$ & \\
\hline ", , & $+t+$ & Omitted. & --- & \\
\hline " 2 & $+t+$ & --- & --- & Case 4, Table II. \\
\hline,, & $+t+$ & --- & --- & \\
\hline,$"$, & $+t+$ & --- & $-\cdots$ & \\
\hline " 3 & --- & --- & ---1 & \\
\hline " $"$ & --- & --- & --- & \\
\hline$\Rightarrow 4$ & $+t+$ & $+t+$ & $-\cdots$ & \\
\hline , 5 & --- & --- & --- & Case 3, Table III. \\
\hline , 6 & --- & --- & --- & Case 4, Table IV. \\
\hline , 6 & --- & --- & --- & \\
\hline , 7 & $+t+$ & $+t+$ & $t+t$ & $\begin{array}{l}\text { Case 12, Table IV., } \\
\text { old serum. }\end{array}$ \\
\hline , 8 & $++t$ & $+t+$ & $+t+$ & Old serum. \\
\hline , 9 & -- & --- & --- & \\
\hline , 10 & $+t+$ & ++- & $\ldots--$ & Case 6, Table II. \\
\hline , , & $+t+$ & ++- & --- & \\
\hline , ", & $t+t$ & $+t+$ & --- & \\
\hline,, 11 & $-\cdots-$ & --- & --- & Case 7, Table IV. \\
\hline, 12 & ++- & ++- & ++- & $\begin{array}{l}\text { Case 17, Table IV., } \\
\text { serum deteriorating. }\end{array}$ \\
\hline, 13 & $t+t$ & $+t+$ & --- & Case 6, Table III. \\
\hline, 14 & --- & +-- & --- & Case 20, Table IV. \\
\hline , " & --- & --- & --- & \\
\hline 9, & --- & $+++^{*}$ & --- & *Obriously a mistake. \\
\hline, 15 & --- & --- & --- & \\
\hline ", , & $--\cdots$ & --- & --- & \\
\hline , 16 & $+t+$ & $t+t$ & --- & \\
\hline, 17 & $+t+$ & $+t+$ & $-\cdots$ & \\
\hline, 18 & $-\cdots-$ & --- & --- & Case 9, Table III. \\
\hline, 19 & $-\cdots$ & --- & --- & \\
\hline , 20 & $-\cdots$ & --- & --- & \\
\hline , 21 & --- & $-\cdots-$ & $-\cdots$ & Case 18 , Table IV. \\
\hline
\end{tabular}

Cases 15 and 16 were hereditary syphilitics. Case 15 was under treatment for years. Case 17 was their mother.

The results obtained with the cancer extract are very much the same as those obtained with the standard antigen. Not only was the reaction negative with a serum derived from a patient affected with rectal carcinoma, but every cancer case gave a negative reaction with the cancer extract. Neither the site of the tumour nor its histo-pathological characters had any influence upon the test. Only syphilitic sera were positive; but here, again, the cancer extract is inferior. Thus Case 2 (No. 4, Table II.) is a syphilitic whose serum invariably gives a positive reaction with the standard antigen, yet it was on no occasion possible to obtain a similar result with the cancer extract. This fact is remarkable, because the serum from Case 10 (No. 6, Table II.), which belongs to a patient whose clinical manifestations are very similar to those of Case 2, gave a positive reaction with both extracts, although here, again, the cancer extract was less sensitive.

As conclusions from these experiments I venture to put forward: 1. As an active etiological factor syphilis plays a small rôle in cancer, if any at all. 2. Epithelioma of the tongue is far more frequently preceded by syphilis than any other form of cancer. 3 . The right to place lingual cancer amongst the parasyphilitic lesions, next to tabes and general paralysis, must be questioned. 4. It is possible to prepare an antigen extract for Wassermann's reaction from purely cancerous material. 5. A sero-diagnosis of cancer on the lines of Wassermann's reaction is at present not possible.

My sincere thanks are due to Dr. A. Paine, director of the Cancer Hospital Research Institute, and to the staff of the Cancer Hospital for the liberal way in which they placed the necessary laboratory and clinical material at my disposal.

\section{A CASE OF APPENDICITIS ILLUSTRATING THE NECESSITY OF EARLY OPERATION.}

By D. D. MALPAS, M.D., $\triangle N D$

Pн. DE LOSTALOT, M.D.

With a Pathological Report by Dr. SABRAzÉs.

Two papers-one on the "Hidden Dangers of Appendicitis," by Mr. Herbert Paterson, and the other on "Our Inability to Diagnose Gross Lesions of the Appendix," by Mr. E. M. Corner-published in THE LANCET of May 13th and 20th respectively, are of such interest and importance that I should like to be permitted to supplement them with a short history of my own case, in which I underwent an operation for the above disease on Dec. 3rd, 1910 (performed by Dr. de Lostalot of Biarritz), with a view, if possible, to emphasise the plea for early operation.

Twenty years ago I had a severe attack of appendicitis, from which I made a slow recovery under the then usual treatment, and between that time and the month of October, 1910, I am not aware that I have had any recurrence of the disease. For three or four days during the month of October, 1910, I suffered from slight vague pains in the right iliac fossa. I was travelling at the time, and did not pay much attention to them, though I thought they were probably due to appendicular disease. These symptoms passed off in a few days. On the evening of Nov. 30th I felt unwell, tired, and "shivery." I had no pain or abdominal discomfort, no nausea, and the appetite was unimpaired. My temperature, however, was $96.2^{\circ} \mathrm{F}$., my pulse being 68 to 70 . The very low temperature puzzled me, but I confess I thought but little of it, and that night I slept well. On the morning of Dec. 1st I was suffciently rested to get up and prepare for the day's work -a very wet, cold day-and I breakfasted as usual. At this time my temperature was $96.4^{\circ}$ only, and the pulse was 68 , the bowels being open and the tongue clean. Now on moving about I began to feel vague abdominal discomfort, with shooting fains occasionally in the region of the gall-bladder. I had no nausea and went out to pay some visits. Whilst driving I found that the jolting of the carriage gave me pains in the right iliac fossa, never severe but annoying. On returning home I asked Dr. de Lostalot to come to see me. His diagnosis and prescription were as follows: "F́videmment menacé de l'appendicite, allez au lit et à l'eau." At 8 P M , after a perfectly quiet afternoon in bed Dr. de Lostalot kindly visited me again and we discussed the advisability of an operation. Things were in no way considered urgent; on the other hand, why delay? This opinion was confirmed by Dr. Moynac of Bayonne, who saw me at $7.30 \mathrm{AM}$. on Dec. 2nd. In the evening of this day I drove up to the surgical clinic belonging to Dr. de Lostalot ready to be operated on at 9.30 A.M. the next day. I should say that now all pain and 
discomfort left me; my temperature had risen to $97 \cdot 6^{\circ}, \mathrm{my}$ pulse was 70 , and that night I slept sufficiently well.

On the morning of Dec. 3rd I walked down to the operating theatre, having neither ache nor pain about me, reassured by Dr. Moynac, who kindly gave me chloroform, saying, "Ca sera une affaire de 15 minutes." In just 50 minutes I was back on my bed and 10 minutes later awake from the chloroform. And now I must leave Dr. de Lostalot to describe what he found.

" On opening the abdomen," says Dr. de Lostalot, " a clear yellow gelatinous fluid escaped in considerable quantity. The appendix was difficult to find since it was intimately adherent to the bowel deep down in the iliac fossa necessitating the drawing out of the whole of the small intestine on to the table, and closely enveloped in a yellow gelatinous mass of tissue. This with the appendix was taken away, a drainagetube was left in, and the wound was closed in the usual way."

The appendix with the yellow gelatinous substance attached to it was forwarded for examination to Dr. Sabrazés, the distinguished professor of pathology at Bordeaux, whose report thereof follows.

The one point important to notice as bearing upon the question of operating or not as early as possible being the existence of a large perforation, the following questions arose. Did this occur at or about the time, some 56 hours before operation, in which the temperature had fallen to $96.2^{\circ}$ ? What would have been the consequences of delay in operation, say, of another 24 hours or so ? Certainly on the day of operation, as far as my feelings were concerned, I was apparently well.

\section{Rapport du Professeur SABRAzÉS.}

Il nous a été remis par le Docteur de Lostalot, en même temps que l'appendice, une matière d'aspect gélatineux, mollasse, d'un blanc hyalin impar rosé grumuleux, d'un volume d'un cuf de pigeon. Elle est constituée par $d u$ mucus fibrillaire et hyalin concrété, enrobant de nombreuses cellules, éléments mononuclées on en petits placards, de provenance péritonéale (endothelium desquamé), cellules cylindriques calciformes ou à plateau, d'origine intestinale (dans l'éspèce appendiculaire); leucocytes polynuclées neutrophiles. Ce mucus recèle quelques microbes en batonnets du type bacterium coli. L'appendice est considérablement déformé; les deux tiers inférieurs ont le calibre du bout $d u$ petit doigt. La paroi rigide présente des foyers de calcification; une écaille calcaire faisant corps avec la séreuse pointe en dehors; une carapace de calcification courre une des faces, se confondant avec les diverses tuniques de l'organe. Un peu au-dessus de cette bande calcaire existe une perforation béante large d'un millimètre et demi. Cette partie renflée de l'appendice ne communique plus avec le segment supérieur normal; elle forme une sorte de vase clos, rompu latéralement, dans lequel ne trouve ni calcul, ni scybale, ni pus, ni helminthes ; sa paroi est inégale, engluée de mucus, hérissée de quelques expansions fibreuses calcaires et aussi de saillies papilliformes. Sur les coupes pratiquées au-dessus de la perforation la lumière de l'appendice mesure 2 millimètres sur 5; l'épaisseur de la paroi est de 2 millimètres. Unilot de calcification occupe la musculeuse ; il apparait granuleuxet fissuraire après décalcification à l'acide formique. Toute la paroi est profondément modifiée, sclérosée, en dégénerescence hyaline et calcaire; ses vaisseaux sont pour la plupart oblitérés; les fibres élastiques sont gonflées.

Les saillies constatées dans la cavité appendiculaire sont de divers ordres: l'une d'elles est purement fibreuse s'infiltrée en un point de cellules conjonctives dégénerées. Une autre saillie est un petit polype glandulaire véritable adénome mucipare, à cellules cylindriques longues, et fléchies sur elles-même formant une végétation longue de 2 millimètres ; les digitations glandulaires qui la constituent sont engluées d'un mucus compact qui s'exsude dans la cavité de l'organe, et entraîne un bon nombre de cellules qui l'élabo. rent: il en résulte des exsudats mucineux analogue à ceux qui ont été trouvés autour de l'appendice. La coque calcaire sitvée au-dessus du point perforé ne montre pas de zones d'ossification hétéroplastiques, pas de tubercules, pas d'actinomyces. Dans les divers segments examinés, la paroi ne contient ni infiltration leucocytique, ni cellules plasmatiques, ni lymphocytes, ni eosinophiles; elle est en quelque sorte momifiée. En résumé: Pseudo-myxome du péritoine autour d'un appendice sclérosé, calcifé, perforé dans lequel un adénome glandulaire hypersecrète du mucus et s'effrite.

Biarritz.

\section{CHLORETONE IN SEA-SICKNESS.}

BY D. A. WELSH, M.A., M.D. EDIN. PROFESSOR OF PATHOLOGY, UNIVERSITY OF SYDNEY.

ONE of the minor ailments which yet may cause much distress is sea-sickness, and anything which may lessen this form of misery is worth noting. On a voyage last year from Sydney to London I had occasion to test the value of chloretone (supplied as tri-chlor-tertiary-butyl alcohol) on myself and other passengers. On the way to Adelaide (August 31st) the weather was very rough and though I did not vomit I was rather miserable. In particular, when I tried to write in the saloon, I became so nauseated that I was forced to stop. Being only a moderate sailor, and being anxious to finish a paper before leaving Australia, I bought in Adelaide 100 capsules of chloretone, 5 grains in each. I took 10 grains at night on Sept. 1st, soon after leaving Adelaide, and 5 grains thrice daily on the 2 nd, 3rd, and 4th, while crossing the Great Australian Bight. As is usual at that time of the year, the Bight was rough and there was a strong head wind, so that the boat pitched heavily all the way across. Nevertheless, I was able to spend several hours daily writing in the saloon without the slightest feeling of nausea; I had some headache, but a good appetite. I was not conscious of any hypnotic effect ( $\mathrm{my}$ sleep being disturbed every night by the movement of the boat), nor indeed of any effect other than the abolition of nausea. But the contrast was most marked between my feeling of comparative comfort, even when writing, after I had taken chloretone, and my sensations of impending disaster when I had tried to write before. Angust 31st and Sept. 2nd, 3rd, and 4th were the roughest days of the whole voyage, but the Indian Ocean and Arabian Sea were by no means quiet, and I occasionally took 5 grains during the rougher weather, with the result that any incipient nausea soon passed off.

On the morning of Sept. 2nd most of the women were sick on deck. The worst was a girl about 20 years old, who was completely prostrated and who vomited frequently. She had 10 grains, but she vomited immediately afterwards, and as I feared the capsules had gone overboard I gave her another 10 grains within half an hour of the first dose. She very soon fell asleep in her chair without being sick. She woke about noon, vomited once, but the prostration had to a large extent passed off, and she had 5 grains more. She took a little lunch and later some dinner on deck, and was not again sick until she went to her cabin for the night, when she vomited before she could get into bed. After this she had 5 grains and passed a good night. Next morning (Sept. 3rd) she took 5 grains before rising, and three similar doses throughout the day. She was able to take all her meals on deck and was never sick. On the 4th the same treatment was carried out with like result. This was a pretty severe test, because the girl was known to be a bad sailor, because she was prostrated by sickness before treatment was begun, and because the weather was increasingly rough for three days after.

Some of the other women were also relieved of nausea by 5 or 10 grains occasionally repeated. Another young woman who joined the boat at Fremantle was very sick on deck next morning (Sept. 6th), prostrated, and romiting repeatedly. She took 10 grains, was nut again sick, and soon began to feel less miserable. A third capsule was given in about an hour, and a fourth in the afternoon ; by evening she felt well enough to come to dinner in the saloon.

But the most remarkable case of all was that of a young Cingalese student who had never been to sea before and who joined at Colombo. As soon as the boat reached open water he became acutely sea-sick with continual vomiting and retching for nearly three days. He was unable to leave his cabin, and I did not know of his condition until the morning of the third day, when the ship's medical officer (who had in vain tried to check the sickness with the remedies at his disposal) asked if he might have some chloretone. In case vomiting should occur before the capsules were dissolved the medical officer took 10 grains of the powder alone, put it on the patient's tongue, and made him wash it down with water. The patient had vomited 14 times that morning, but after this dose he did not romit again. Later in the day he had another 10 grains, took a little food, and rested quietly in his cabin. Next morning he was able to come on deck and to take his meals in the saloon. He had a few capsules at intervals during the rest of the voyage, and left at Marseilles without again having suffered from sea-sickness. 